Al-Uqud: Journal of Islamic Economics E-ISSN 2548-3544, P-ISSN 2549-0850 Accredited No. 28/E/KPT/2019
Volume 4 Issue 1, January 2020

DOI:10.26740/al-uqud.v4n1.p32-47

Page 32-47

\title{
What Attracts Guest to Stay? Brand Identity, Religiosity, and Reference Group towards Decision to Choose Sharia Hotel
}

\author{
Winka Alfi Jayanti ${ }^{1}$, Sri Setyo Iriani ${ }^{2 *}$ \\ 1,2 Department of Management, Faculty of Economics, Universitas Negeri Surabaya \\ Jalan Ketintang, Surabaya 60231, Indonesia
}

\begin{abstract}
Indonesia has one of largest Muslim population in the world. Therefore, currently it is not surprising that Sharia Branding is currently widely used by business entities ranging from banking to the hospitality business. This phenomenon is observed in the city of Surabaya in which Sharia hotels are mostly found such as the Namira Syariah Hotel. Nevertheless, the growth in the number of consumers who stay in Syariah hotels is not as much as conventional hotels. Therefore, the purpose of this research is to (1) to analyze the effect brand identity on the decision of consumers to stay at the Hotel Namira Syariah Surabaya, (2) to analyze the effect the consumer religiosity on consumers decision to stay at the Hotel Namira Syariah Surabaya, (3) to analyze the effect of the reference group to the decision to stay at the Hotel Namira Syariah Surabaya. This type of research uses a causal research approach. The population in this research is infinite but have ever stayed at the Hotel Namira Syariah Surabaya only but to all Muslim who at least 17 years old. The sample collection technique used is non-probability sampling with the number of samples is 210 respondents. The research instrument used a questionnaire, while data analysis used multiple linear regression analysis. From the results of the discussion and analysis of the data, it can be concluded that there is a positive influence of brand identity, religiosity and reference groups on the decision to stay at the sharia hotel.
\end{abstract}

Keywords: Brand identity; Religiosity; Reference group; Decision to stay; Sharia hotel

Paper type: Research paper

*Corresponding author: srisetyo@ unesa.ac.id

Received: September 22, 2019; Accepted: January 11, 2020; Published: January 20, 2020

Cite this document: Jayanti, W. A. \& Iriani, S. S. (2020). What Attracts Guest to Stay? Brand Identity, Religiosity, and Reference Group towards Decision to Choose Sharia Hotel. Al Uqud: Journal of Islamic Economics, 4(1), 32-47. doi: http://dx.doi.org/10.26740/al-uqud.v4n1.p32-47

Copyright (C) 2020, Al-Uqud: Journal of Islamic Economics http://journal.unesa.ac.id/index.php/jie 


\begin{abstract}
Abstrak: Indonesia memiliki populasi muslim yang banyak, sehingga tidak mengherankan jika Branding Syariah saat ini banyak digunakan oleh entitas busnis mulai perbankan sampai dengan bisnis perhotelan. Fenomena ini terlihat di kota Surabaya yang banyak ditemui Hotel Syariah seperti Hotel Namira Syariah Surabaya. Namun pertumbuhan jumlah konsumen yang menginap di Hotel Syariah tidak sebanyak dengan Hotel Konvensional. Oleh sebab itu tujuan penelitian ini untuk. (1) Untuk menganalisis brand identity terhadap keputusan konsumen menginap di Hotel Namira Syariah Surabaya, (2) Untuk menganalisis religiusitas terhadap keputusan konsumen menginap di Hotel Namira Syariah Surabaya, (3)untuk menganalisis pengaruh kelompok referensi terhadap keputusan menginap di Hotel Namira Syariah Surabaya. Jenis penelitian ini menggunakan pendekatan riset kausal. Populasi dalam penelitian ini bersifat infinite dengan kriteria responden adalah tamu yang pernah menginap di Hotel Namira Syariah Surabaya, beragama islam dan berusia minimal 17 tahun. Teknik pengumpulan sampel menggunakan non-probability sampling dengan jumlah sampel sebanyak 210 responden. Instrumen penelitian menggunakan angket sedangkan analisis data menggunkan analisis regresi linear berganda. Berdasarkan hasil analisis data dapat disimpulkan bahwa ada pengaruh positif identitas merek, religiusitas dan kelompok referensi terhadap keputusan menginap di hotel Syariah.
\end{abstract}

Kata kunci: Brand identity; Religiusitas; Kelompok referensi; Keputusan menginap; Hotel syariah

\title{
INTRODUCTION
}

Indonesia has a moslem population nearly 207.176 .162 million or $87.18 \%$ of the total population in Indonesia. However, although has recognized as huge potential of Indonesia in global economy, according to the Minister of the Economy Republic of Indonesian, Indonesia only become a market for Islamic products/service. According to the report, in the year 2018-2019, Indonesia's sharia-based economy ranked $10^{\text {th }}$ in the world as its position as largest Muslim population of the world. Nevertheless, Indonesia is not only the largest consumer in the world but also become the manufacturer for many halal products or service such as sharia accommodation.

In East Java, accommodation industry in which hospitality business and economic development are operated have increased each year, starting from the 2012- 2016, that grow from 1,923 to 3,397 (BPS Provinsi Jawa Timur, 2016). For this province itself, most sharia hotels located in the city of Surabaya, one of them is Hotel Namira Syariah Surabaya. It is one of hotel that do branding so that the identity is embedded in the minds of consumers. This hotel is the largest Islamic hotel in Surabaya and has the most strategic location for tourists to find lodgings, so the branding of the hotel should always be intensified. If the brand identity is managed properly, it will generate positive perceptions, attitudes and behaviour of stakeholders. For example, from a consumer standpoint, the creation of a unique identity, a coherent and distinctive can improve company's value (Coleman et al., $\underline{2011)}$.

Meanwhile, sharia hotels also began to develop in East Java. According to the Head of the Development, Department of Culture and Tourism of East Java Province, the sharia-labeled hotels mostly found in Surabaya and Jombang 
(www.surabayafamily.com, 2017). The development of accommodation industry in other cities such as Sidoarjo, Malang, Lamongan also started to developed rapidly (Tourism and Culture Office, 2016). Being the second largest city in Indonesia, Surabaya combines elements of business and tourism which certainly makes accommodation one of the elements that always needed. Hotel industry in in big cities is very competitive as these cities have developed their tourism. The high number of visitors lead to high demand for lodging with various rates according to multiple segments of consumers. One of the hotels does branding to ingrain its brand identity to the minds of consumers is the Namira Syariah Hotel Surabaya. It is the largest sharia hotel in Surabaya and situated in the strategic location in Surabaya which close to the tourism main destination. Therefore, it is more accessible for tourist who look for a place to stay. The hotel branding should have to be improved because if it is managed properly, it will create positive perceptions, attitudes and behaviors of different stakeholders. For example, based on the consumer perspective, the creation of unique, coherent and distinctive identities can add value to a company's products (Coleman et al. 2011).

In addition to the brand's identity, one's commitment to implement their religion recognized as religiosity also affects the person in deciding to stay in hotel. Johnson, et al (2001) as the extent to which individuals are committed to religion and the teachings contained in it such as a commitment to implement religious attitudes and behaviour.

Religiosity has several dimensions. According to Glock \& Stark (1965) that summarized in the study of Nasrullah (2015), religiosity including Dimensional Confidence/ideology (ideological), Dimension Practice (ritualistic), Dimension Experience (experiential), Dimensions of Religious Knowledge (intellectual), and the dimensions of consequences (consequential). In making purchasing decisions, consumers who have high levels of religiosity tend to be less impulsive, more mature in their behaviour, discipline, and responsible (Alam, et al, 2011). The results of the study (Abhimantra, et al 2013) implied a conclusion intact factors that influence the decision of savings in Islamic banks. In making purchasing decisions, consumers who have a high level of religiosity tend to be less impulsive, more mature in behavior, discipline, and responsible (Nature, et al, 2011). The results of the study (Abhimantra, et al 2013) concluded that there are factors that influence savings decisions in Islamic banks. One of them is to do a comparison by finding several references from various sources, for example from the surrounding environment, or what is commonly called a reference group.

In Hartatin (2016) research, reference groups influence consumer purchasing decisions with indicators such as knowledge, experience, activity, attractiveness and credibility of the reference group. Research conducted by Utami et al (2015) states that the factors of religiosity, reference groups and motivation have a partial and simultaneous effect on savings decisions in Islamic banks. This result is different from research conducted by Zahra et al. (2016) which shows that the reference group has no significant effect on consumer purchasing decisions. Based on the background above, the authors chose the Namira hotel as a research subject because this hotel is the largest sharia hotel in Surabaya and has the most number of visitors compared to other sharia hotels in Surabaya. Thus, this study aims to 
Winka Alfi Jayanti, Sri Setyo Iriani: What Attracts Guest to Stay? Brand 35 Identity, Religiosity, and Reference Group towards Decision to Choose Sharia Hotel

determine the effect of brand identity, religiosity and reference groups on overnight decisions (a study of Namira Syaiah Hotel Guests in Surabaya.

\section{RESEARCH METHODS}

This research uses a causality approach. This causality approach is used to determine the causal relationship of the independent variable and the dependent variable on a particular phenomenon and determine the nature of the relationship between the independent variable and the estimated influence (Malhotra, 2009). The research design is as follows:

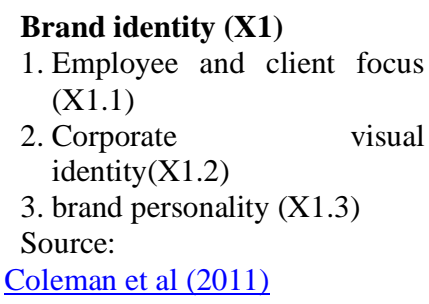

1. Religious Value (X2.1)

2. Religious Beliefs (X2.2)

3. Ritualistic (X2.3)

Source: Nasrullah (2015),

The reference group (X3)

1. Reference group knowledge about the product/service (X3.1)

2. The credibility of the reference group (X3.2)

3. The experience of the reference group (X3.3)

4. the activeness of the reference group (X3.4)

Source: Anggel, et al (in

Hartatin, 2016), Jalasena (2013),

The population in this study is infinite with the following criteria:

- Respondents are guests who have stayed at the Namira Syariah Hotel in Surabaya

- Respondents are consumers who are Muslim

- Respondents are consumers who are at least 17 years old.

Furthermore, the sampling technique in this study is purposive sampling where the sampling technique used is non-probability sampling to produce 200 respondents. In the sample added 5\% of the total number of respondents, so that the total number of respondents used in this study was 210 respondents. Data collection techniques carried out through questionnaires, interviews to obtain primary data. Meanwhile, 
to obtain secondary data, data obtained from journals, books, articles, internet and other research results relevant to the topic under study. Data analysis techniques in this study used multiple linear regression with the help of SPSS (Statistics Program for Social Science) for Windows version 18.0

\section{RESULTS AND DISCUSSION}

\section{Characteristics and responses}

Characteristics of respondents are divided by gender. Male respondents dominated 113 respondents $(53.8 \%)$. While based on the age of the respondents, respondents with an age range of 31-45 years were more dominant than the others by $324 \%$. Based on the type of respondent's job, private employees dominate more than others. The following table 1 shows the characteristics of respondents based on gender, age and occupation:

Table 1. Characteristics of Respondents

\begin{tabular}{llrr}
\hline No. & $\begin{array}{c}\text { Characteristics of } \\
\text { respondents }\end{array}$ & \multicolumn{2}{c}{ Total } \\
\cline { 2 - 4 } 1 & Gender: & amount & Percentage \\
\hline & a. Male & 113 & $53.8 \%$ \\
b. female & 97 & $46.2 \%$ \\
\hline \multirow{2}{*}{2 Total } & Age: & 210 & $100 \%$ \\
\hline a. 17-25 Years & 34 & $16.2 \%$ \\
b. 26-30 Years & 64 & $30.5 \%$ \\
c. 31- 45 Years & 68 & $32.4 \%$ \\
d. 46-55 Years & 29 & $13.8 \%$ \\
e. 56-60 Years & 15 & $7.1 \%$ \\
\hline & Total & 210 & $100 \%$ \\
\hline 3 & Type of work : & & \\
a. civil servant & 52 & $24.8 \%$ \\
b. private employees & 64 & $30.5 \%$ \\
c. student/student & 27 & $12.9 \%$ \\
d. entrepreneur & 31 & $14.8 \%$ \\
e. others & 36 & $17.1 \%$ \\
\hline & Total & 210 & $100 \%$ \\
\hline
\end{tabular}

Source: Data processed

\section{Test Normality}

The histrogram graph shows the distribution that skewed to the right. On a normal graph, plots of normal probability points spread around a diagonal line. In statistical testing, the significance value of the KS test is $0.175>0.05$. Moreover, in this study multiple linear regression models are used to meet the rules of normality.

\section{Test Multicollinearity}

Based on the results of data processing, the significance value of the three independent variables is more than 0.05 , so it can be concluded that the multiple linear regression model is free from heteroscedasticity problems. 


\section{Heterokesdasticity}

Based on the results of significant value data if three independent variables more than 0.05 is finished it can be concluded that the multiple linear regression model is free from the problem of heteroscedasticity.

\section{Multiple Linear Regression Analysis}

The multiple linear regression model obtained as follows:

$$
\mathrm{Y}=-298+0,520 \mathrm{X} 1+0,273 \mathrm{X} 2+0,252 \mathrm{X} 3
$$

Information:

$-298=\mathrm{A}($ constant $/$ numbers have no charge $\mathrm{X})$

$\mathrm{Y}=$ Decision stay

$\mathrm{X} 1=$ Brand identity

$\mathrm{X} 2=$ Religiosity

$\mathrm{X} 3=$ Reference Group

The interpretation of the regression model above is as follows:

a. Constant value $(\alpha)$ Constant value $(\alpha)$ value of -298 can be interpreted that brand identity, religiosity and reference groups have a value of 0 (zero), which affects the value of the decision to stay at the Namira Syariah Hotel in Surabaya of 0.298 . The negative sign on the value means there is no brand identity, religiosity and reference groups, so consumers will not make the decision to stay at the Namira Syariah Hotel in Surabaya. It can be concluded that the independent variables of brand identity (X1), religiosity (X2), and reference groups (X3) can influence the dependent variable (decision of staying overnight (Y).

b. The coefficient value for the brand identity variable (X1) is 0.520 . The positive sign means that brand identity (X1) can have a positive effect on the decision to stay overnight (Y). So if the brand identity (X1) is positive, the higher the consumer's decision to stay at the Namira Syariah Hotel in Surabaya.

c. The coefficient value for the variable religiosity (X2), is 0.273 . The positive sign means that religiosity (X2) can have a positive effect on the decision to stay overnight (Y). So that if religiosity (X2), the higher the higher the decision of consumers to stay at the Namira Syariah Hotel in Surabaya.

$\mathrm{d}$. The coefficient value for the reference group variable (X3), is 0.252 . The positive sign means the reference group (X3), can have a positive effect on the decision to stay overnight (Y). So if the reference group (X2) is positive, the higher the decision of consumers to stay at the Namira Syariah Hotel in Surabaya.

e. Based on the explanation in the table above, brand identity (X1) is a variable that must be considered in improving the decision to stay at the Namira Syariah Surabaya hotel because it has the most influence, 0.520 .

The statistical results are in appendix 1.

\section{Test of Feasibility}

In a multiple linear regression analysis produces a value of R (correlation) and R2 (coefficient of determination). The magnitude of the contribution of independent variables namely brand identity, religiosity and reference groups to the dependent variable is the decision to stay overnight. The adjusted $R$ Square coefficient value 
of 0.535 is equal to $53.5 \%$ so it shows that the model used can explain the variables studied that is equal to $53.5 \%$ while the remaining $47.5 \%$ is explained by other variables outside the variables examined in this research. The statistical results are in appendix 2.

\section{Hypothesis Test}

The T-test (partial)

To test the effect of each of the brand identity, religiosity and reference group variables on the decision to stay at the Namira Syariah Hotel in Surabaya, this study uses the $t$ test. independent variables are declared influential when having sig. $<0.05$.

a. Brand identity (X1) partially influences the stay decision variable (Y). The above table produces the $t$ value of the brand identity variable of 8,257 with sig. $0,000>$ 0.05. It means Ho is accepted and $\mathrm{Ha}$ is rejected or it can be concluded that brand identity variable (X1) influences the decision to stay at the Namira Syariah Hotel in Surabaya.

b. Religiosity (X1) partially influences the overnight decision variable (Y). The table above produces the value of $t$ calculated religious variables of 3.144 with sig. 0.002>0.05, then Ho is accepted and Ha is rejected. So it can be concluded that the variable of religiosity (X2) influences the decision to stay at the Namira Syariah Hotel in Surabaya.

c. The reference group (X3) partially influences the overnight decision variable (Y). The table above produces the value of $t$ calculated religious variables is 4,820 with sig. 0,000>0.05, then $\mathrm{Ho}$ is accepted and $\mathrm{Ha}$ is rejected. So it can be concluded that the reference group variable (X3) influences the decision to stay at the Namira Syariah Hotel in Surabaya.

The statistical results are in appendix 3.

\section{The Effect of Brand Identity on the Decision to Stay at Hotel Namira Syariah Surabaya}

The results of this study were analyzed by multiple linear regression which aims to find the greatest equation results where it will prove that the brand identity variable (X1) has a positive effect on the stay decision (Y) at Namira Syariah Hotel, Surabaya. This influential relationship will explain how consumers consider brand identity when staying at the Namira Syariah Hotel in Surabaya. As the theory from previous research states that the higher the level of consumer knowledge about brand identity or the more consumers trust brand identity, then their tendency to stay at the Namira Syariah Hotel in Surabaya is higher.

This theory was put forward by Surachman (2008) which states that brand identity means a set of brand associations that are the goals or ideals of the brand strategy itself to create or maintain the continuity of a brand in the market. The results of this study also reinforce the results of Roma \& Juanim (2009) which states that brand identity has a positive and significant influence on product purchasing decisions. Some factors that cause the conformity of this study with previous research is because this study also uses respondents with similar gender 
characteristics, namely men with an age range of 31-45 years and work as employees.

The characteristics of these respondents are consistent with the segmentation of the Surabaya Namira Syariah Hotel which focuses on middle and upper income and fixed income economic segmentation. Male respondents aged 31-45 were more dominant in this study because the majority of male guests who came to the Namira Syariah Hotel in Surabaya were not only staying overnight, but were also attending certain events related to their work.Based on respondents' answers, the largest average value is brand identity variable with corporate visual identity indicator in item X1.2.1 which reads "The Namira Syariah Surabaya Hotel Logo is very easily recognized" This explains that the main reason for respondents who stay at the Namira Syariah Hotel Surabaya is because the logo of the Surabaya Namira Syariah Hotel is very easy to recognize. This statement shows that the most dominant brand identity owned by the Namira Syariah Surabaya Hotel is a logo, because its logo identify = Namira Syariah Surabaya Hotel as a hotel with a sharia concept.

In this study, brand identity variables were measured using two indicators from Coleman et al. (2011) namely: employee \& client focus and corporate visual identity. Of the two indicators, the one with the most dominant average value is the corporate visual identity because respondents understand that the corporate visual identity can be reflected from the symbols or logos owned by the Namira Syariah Surabaya Hotel which become sharia service brand identities. Furthermore, if seen from the statistical results the average respondent's answers in the brand identity variable. many respondents agreed that brand identity influenced their decision to stay at the Namira Syariah Hotel in Surabaya.

\section{The Influence of Religiosity on the Decision to Stay at the Namira Syariah Hotel in Surabaya}

The results of this study were analyzed with multiple linear regression analysis which proves that the variable of religiosity (X2), positively influences the decision to stay (Y) at Namira Syariah Hotel, Surabaya. This means consumers consider religiosity when staying at the Namira Syariah Hotel in Surabaya. The higher the level of consumer religiosity, the possibility of consumers to make a decision to stay at the Namira Syariah Hotel in Surabaya is higher. This is because someone who has a high level of religiosity will prioritize matters of the afterlife rather than worldly and will try to obey the commands in accordance with beliefs and stay away from all its prohibitions. The variable of religiosity has a positive influence on the decision to stay at the Namira Syariah Hotel in Surabaya because the statistical results of the largest average on the variable of religiosity is on the ritualistic indicator (practice) with the statement item X2.3.2 stating "I do fasting during Ramadan". this explains that respondents who stay at the Namira Syariah Hotel in Surabaya are, in practice, respondents with high religiosity, which is reflected in their adherence in carrying out Islamic Shari'a such as fasting during Ramadan. This means that the level of religiosity affects consumers when making a decision to stay at the Namira Syariah Hotel in Surabaya.

The results of the study support the theory of Sumarwan (2015) which says that religious teachings will affect the attitudes, motivations, perceptions, and 
behavior of consumers in consuming goods and services. Consumers will tend to apply the teachings they hold as a basis for making decisions in terms of consuming goods or services. This religiosity shows one's commitment to religion and the teachings contained therein. Thus, the high level of consumer religiosity can influence the decision to stay at the Namira Syariah Hotel in Surabaya. In addition, these results also support research conducted by Delener (1990) and Dibb (2004) (in Nasrullah, 2015) stating that religiosity is one of the important driving factors and can influence consumer behavior. As Nature, et al (2011) who states that consumers who have a high level of religiosity tend to be less impulsive when making purchasing decisions. This is because they tend to behave in a more mature, disciplined, and responsible manner. This also corroborates the research results of Abhimantra, et al (2013) which states that there are factors that positively influence savings decisions in Islamic banks, one of which is consumer religiosity.

Respondents in this study were dominated by male respondents in the age range 31-45 years who worked as private employees. Men are more dominant in this study because men have more opportunities in carrying out their religious teachings compared to women. This study was dominated by respondents aged $31-$ 45 years. Because in this study the age range of 31-45 years included in the category of adults who tend to better understand the teachings of Islam that is valuable to him in behavior. A person's life in the adult category tends to have a view of life that is based on religion that will give satisfaction to him. In addition, adults are more free in making choices. Because someone in this phase finds religion as a source of pleasure and happiness that is greater than what he had obtained when he was young. The attitude and interest of someone with an adult category towards religious issues tends to be high and the religious environment that affects them. In addition, as explained that a person's life has entered into the adult category tends not to be influenced by personal pleasure. The interest of people in the adult category on religious matters is also already high. So, the existence of the concept of sharia in the hotel can be considered by consumers in deciding to stay at the Namira Syariah Hotel in Surabaya. The concept of sharia is a problem for adult consumers who are more inclined to stay at the Namira Syariah Hotel in Surabaya because they believe in their belief in religion.

This study uses several indicators to measure religiosity including religious values, religious beliefs and ritualism. The highest average value on the variable of religiosity lies in the ritualistic indicator (practice) related to one's commitment and obedience to the teachings of Islam, for example in deciding to stay at the Namira Syariah Surabaya Sharia hotel. This shows that the average respondent's answers in the religiosity variable agreed that religiosity influenced their decision to stay at the Namira Syariah Hotel in Surabaya.

\section{The Influence of The Reference Group on the Decision to Stay at the Namira Syariah Hotel in Surabaya}

With multiple linear regression analysis, the reference group variable (X3), positively influences the stay decision (Y) at the Namira Syariah Hotel in Surabaya, meaning that consumers consider the opinion of the reference group when staying at the Namira Syariah Hotel in Surabaya. This means, the higher the influence of 
the reference group, the likelihood of consumers to make a decision to stay at the Namira Syariah Hotel in Surabaya is higher.In the reference group variable in the statement item that has the highest value is the experience indicator of the reference group X3.3.1. For example the high agreed class interval number on the statement item "I am interested in staying at Namira Syariah Hotel in Surabaya after hearing information from friends or colleagues my work ". This shows that respondents strongly agree if the reference group influences the customer when making a decision to stay at the Namira Syariah Hotel in Surabaya. The reference group in this study are consumers' friends or colleagues where consumers will trust more information from direct experience by friends / colleagues to stay at the Namira Syariah Hotel in Surabaya. This then becomes their decision in making a decision to stay at the Namira Syariah Hotel in Surabaya.

The results of this study are in accordance with the theory put forward by Sumarwan (2011) which mentions the reference group as an individual or group of people that significantly influences a person's behavior. Reference group is a group of individuals or people who have a function as a reference for someone in deciding to make a purchasing decision. These results also support research by Utami et al $\underline{(2015)}$ where the factors of religiosity, reference groups and motivation have a partial and simultaneous influence on savings decisions in Islamic banks. In this study, indicators used to measure reference group variables are using indicators that have been studied by Hartatin (2016) and Jalasena (2013) namely: knowledge of reference groups, credibility of the reference group, experience of the group reference and activeness of the reference group. Male respondents dominate the number of respondents in the age range 31-45 years with work as private employees. Men are more dominant in this study because men have a simpler attitude and minimal conflict, in contrast to women who are mostly more sensitive and use their feelings when making decisions.

Likewise in the case of deciding to stay overnight, men tend to trust and be close to their friends or coworkers compared to women because men tend to like instant process of decision making. In addition, respondents in the age range of 3145 years are included in the category of adults who are more able to understand and can read characters from friends or coworkers. They also tend to have a more mature level of thinking and trusting friends is not random, so trust in someone has certainly been carefully considered. So this determines their decision to stay at the Namira Syariah Hotel in Surabaya.

\section{CONCLUSION}

From the results of the discussion and analysis of the data, it can be concluded that there is a positive influence of brand identity, religiosity and reference groups on the decision to stay at the Namira Syariah Hotel in Surabaya. This study has several limitations including the use of closed questionnaires, so the discussion did not strengthen the research variables because respondents were not given the opportunity to express their opinions directly in the research questionnaire. In addition, the age range in the questionnaire distributed to 210 respondents in this study was not consistent (not the same). 
Based on some of the limitations above, some suggestions for further research are providing deep questions in the form of an open questionnaire so that the variables related in the study can be discussed more deeply. Future research is expected to use the same age range so that research can focus more on the characteristics of certain respondents. Meanwhile, based on this study result, the managerial implications for the company are the Surabaya Namira Syariah Hotel is expected to realize a more comprehensive and in-depth Sharia concept in its marketing strategy so that it can build a stronger brand identity and subsequently attract more consumers to stay at the Namira Syariah Hotel in Surabaya.

\section{REFERENCES}

Alserhan, B. A. (2010). On Islamic branding: Brands as good deeds. Journal of Islamic Marketing. https://doi.org/10.1108/17590831011055842

Ananggadipa, A., Maulina, A. R. \& Agustianingsih, E. (2013). Analisis FaktorFaktor yang Mempengaruhi Nasabah (Mahasiswa) dalam Memilih Menabung pada Bank Syariah. Jurnal Elektronik, Universitas Gunadarma, Vol.5.

https://ejournal.gunadarma.ac.id/index.php/pesat/article/view/1179/1040

Aoun, I., \& Tournois, L. (2015). Building holistic brands: An exploratory study of halal cosmetics. Journal of Islamic Marketing. https://doi.org/10.1108/JIMA05-2014-0035

Balmer, J. M. T. (2017). Advances in corporate brand, corporate heritage, corporate identity and corporate marketing scholarship. European Journal of Marketing. https://doi.org/10.1108/EJM-07-2017-0447

BPS Provinsi Jawa Timur. (2016). Statistik Hotel dan Akomodasi Lainnya di Indonesia.

https://www.bps.go.id/publication/2016/12/09/e843e81d69d49fdc5f79ebd4/ statistik-hotel-dan-akomodasi-lainnya-di-indonesia-2016.html

Butt, M. M., Rose, S., Wilkins, S., \& Ul Haq, J. (2017). MNCs and religious influences in global markets: Drivers of consumer-based halal brand equity. International Marketing Review. https://doi.org/10.1108/IMR-12-2015-0277

Coleman, D. A., de Chernatony, L., \& Christodoulides, G. (2015). B2B service brand identity and brand performance: An empirical investigation in the UK's B2B IT services sector. European Journal of Marketing. https://doi.org/10.1108/EJM-03-2013-0154

Delener, Nejdet. (1990). The Effects of Religious Factors on Perceived Risk in Durable Goods Purchase Decision. Journal of Consumer Marketing, Vol. 7 (3), pp. 27-38. https://doi.org/10.1108/EUM0000000002580

Dibb, Sally \& Essoo, Nittin. (2004). Religious Influences on Shopping Behavior: An Exploratory Study. Journal of Marketing Management, Vol. 20 (7-8), pp. 683-712. https://doi.org/10.1362/0267257041838728

Ghofur, A., Susilo, S., Soedarto, J. P. H., Tembalang, S. H., \& Tembalang, K. S. (2017). Maslaha as the philosophical, political and legal basis on the Islamic banking legislation in Indonesia. Global Journal Al Thaqafah, 7(1), 7-17. http://site.gjat.my/main/3074/index.asp?pageid=183818\&t=volume-7-issue$\underline{1-}$

Copyright (C) 2020, Al-Uqud: Journal of Islamic Economics http://journal.unesa.ac.id/index.php/jie 
Glock Charles Y, Stark Rodney. Religion and Society in Tension. Chicago: Rand McNally; 1965.

Hartatin, Diana \& Simajuntak, Megawati. (2016). The Effect of Value and Reference Group on Young Consumer's Hedonic Buying. Journal of Consumer Sciences, Vol.1 (1), pp. 33-36. https://doi.org/10.29244/jcs.1.1.33$\underline{46}$

Hati, S. R. H., \& Idris, A. (2019). The role of leader vs organisational credibility in Islamic social enterprise marketing communication. Journal of Islamic Marketing. https://doi.org/10.1108/JIMA-02-2017-0018

Hammerl, M., Dorner, F., Foscht, T., \& Brandstätter, M. (2016). Attribution of symbolic brand meaning: the interplay of consumers, brands and reference groups. Journal of Consumer Marketing. https://doi.org/10.1108/JCM-12$\underline{2014-1243}$

Jalasena, Bintang Anoraga. (2013). Pengaruh Gaya Hidup dan Kelompok Acuan Terhadap Keputusan Pembelian Smartphone Merek Samsung Galaxy. Jurnal Ilmu Manajemen, Volume 1 Nomor 4 Juli 2013. https://journal.unesa.ac.id/index.php/bisma/article/view/2774

Johnson, B. R., Joon Jang, S. \& Larson, D. B. (2001). Does Adolescent Religious Commitment Matter? A Reexamination of the Effects of Religiosity on Delinquency. Journal of Research in Crime and Delinquency. Vol. 38 (1), pp. 22-44. https://doi.org/10.1177\%2F0022427801038001002.

Kotler, Philip and Kevin Lane Keller. 2012. Marketing Management, Edisi 14 New Jarsey: Prentice -Hall Published.

Kushwah, S., Shree, D., Rezaei, S., \& Sagar, M. (2019). The impact of culture on consumer's perception of brand identity: Evidences from Gulf countries. Journal of Islamic Marketing. https://doi.org/10.1108/JIMA-12-2017-0146.

Lourenção, M. T. de A., \& Giraldi, J. de M. E. (2017). Development of an identity model for sector brands. Journal of Fashion Marketing and Management. https://doi.org/10.1108/JFMM-10-2016-0097.

Lin, L., \& Chen, Y. (2009). A study on the influence of purchase intentions on repurchase decisions: the moderating effects of reference groups and perceived risks. Tourism Review. https://doi.org/10.1108/16605370910988818.

Maholtra, N., Hall, John, Shaw, M. and Oppenheim, P. (2006). Marketing Research: An Applied Orientation, $3^{\text {rd }}$ ed., pearson Education Australia, Frenchs, M.S.W

Maulan, S., Omar, N. A., \& Ahmad, M. (2016). Measuring halal brand association (HalBA) for Islamic banks. Journal of Islamic Marketing. https://doi.org/10.1108/JIMA-09-2014-0058

Mindrut, S., Manolica, A., \& Roman, C. T. (2015). Building Brands Identity. Procedia Economics and Finance. https://doi.org/10.1016/s22125671(15)00088-X

Mohd Yusof, Y. L., \& Wan Jusoh, W. J. (2014). Islamic Branding: The Understanding and Perception. Procedia - Social and Behavioral Sciences, 130, 179-185. https://doi.org/10.1016/j.sbspro.2014.04.022 
Muhonen, T., Hirvonen, S., \& Laukkanen, T. (2017). SME brand identity: its components, and performance effects. Journal of Product and Brand Management. https://doi.org/10.1108/JPBM-01-2016-1083

Nasrullah, R. (2015). Media Soial Prosedur, Tren, dan Etika, Bandung: PT Remaja Rosdakarya, 2015, pp. 15-47.

Raman, K., \& Naik, P. A. (2004). Long-term profit impact of integrated marketing communications program. Review of Marketing Science, 2(1), 8. https://doi.org/10.2202/1546-5616.1014

Robinson, T., \& Doss, F. (2011). Pre-purchase alternative evaluation: Prestige and imitation fashion products. Journal of Fashion Marketing and Management: An International Journal. https://doi.org/10.1108/13612021111151897

Roma, J. \& Kartika, D. (2009). Brand Identity dan Perilaku Pembelian Produk Blackberry. Jurnal Riset Bisnis \& Manajemen. 2. 24-33. http://dx.doi.org/10.23969/jrbm.v12i2

Roy, D., \& Banerjee, S. (2008). Care-ing strategy for integration of brand identity with brand image. International Journal of Commerce and Management. https://doi.org/10.1108/10569210710776512.

Syed Shah Alam, S. S. A., Mohd, R., \& Hisham, B. (2011). Is religiosity an important determinant on Muslim consumer behaviour in Malaysia? Journal of Islamic Marketing, 2(1), 8396. https://doi.org/10.1108/17590831111115268

Tournois, L., \& Aoun, I. (2012). From traditional to Islamic marketing strategies: Conceptual issues and implications for an exploratory study in Lebanon. In Education, Business and Society: Contemporary Middle Eastern Issues. https://doi.org/10.1108/17537981211251179

Utami, P. J. (2015). Hubungan Religiusitas dengan Perilaku Seksual pada Remaja di SMA Negeri 1 Banguntapan Bantul Yogyakarta. Naskah Publikasi. http://digilib.unisayogya.ac.id/122/1/NASKAH\%20PUBLIKASI.pdf

Viot, C. (2011). Can brand identity predict brand extensions' success or failure? Journal of Product and Brand Management. https://doi.org/10.1108/10610421111134941

Wardhani, W., Sumarwan, U., \& Yuliati, L. N. (2015). Pengaruh persepsi dan preferensi konsumen terhadap keputusan pembelian hunian Green Product. Jurnal manajemen dan organisasi, 6(1), 45-63. https://doi.org/10.29244/jmo.v6i1.12183

Wilson, J. A. J., Belk, R. W., Bamossy, G. J., Sandikci, Ö., Kartajaya, H., Sobh, R., Liu, J., \& Scott, L. (2013). Crescent marketing, Muslim geographies and brand Islam: Reflections from the JIMA Senior Advisory Board. In Journal of Islamic Marketing. https://doi.org/10.1108/17590831311306336. 
Winka Alfi Jayanti, Sri Setyo Iriani: What Attracts Guest to Stay? Brand 45 Identity, Religiosity, and Reference Group towards Decision to Choose Sharia Hotel

Appendix 1. Results of Linear Regression Coefficients Estimates

\begin{tabular}{|c|c|c|c|c|c|}
\hline \multirow[t]{2}{*}{ Model } & \multicolumn{2}{|c|}{$\begin{array}{l}\text { unstandardized } \\
\text { coefficient }\end{array}$} & \multirow{2}{*}{$\begin{array}{c}\begin{array}{c}\text { standardize } \\
\text { d } \\
\text { coefficients }\end{array} \\
\text { beta }\end{array}$} & \multirow[t]{2}{*}{$\mathbf{t}$} & \multirow[t]{2}{*}{ Sig. } \\
\hline & B & Std.Error & & & \\
\hline (constant) & $\begin{array}{c}- \\
.298\end{array}$ & .368 & & -.810 & .419 \\
\hline $\mathrm{BI}$ & .520 & .063 & .466 & 8257 & .000 \\
\hline religiosity & .273 & .087 & .165 & 3144 & .002 \\
\hline $\mathrm{KR}$ & .252 & .052 & .272 & 4,820 & .000 \\
\hline
\end{tabular}

Source: SPSS output 
46 Al-Uqud: Journal of Islamic Economics

Volume 4 Issue 1, January 2020

Appendix 2. Correlation Values and Coefficient of Determination

\begin{tabular}{lcccl} 
Model & $\mathbf{R}$ & R Square & $\begin{array}{c}\text { Adjusted R } \\
\text { square }\end{array}$ & $\begin{array}{c}\text { Std.error of } \\
\text { the estimate }\end{array}$ \\
\hline 1 & $.736 \mathrm{a}$ & .541 & .535 & .336 \\
\hline
\end{tabular}

a. Predictors :( constant), BR, religiosity, KR

b. Dependent variables: KM

Source: SPSS output 
Winka Alfi Jayanti, Sri Setyo Iriani: What Attracts Guest to Stay? Brand 47 Identity, Religiosity, and Reference Group towards Decision to Choose Sharia Hotel

Appendix 3. T-test (partial)

\begin{tabular}{lccccc}
\hline \multicolumn{1}{c}{ Model } & unstandardized coefficient & \multicolumn{2}{c}{$\begin{array}{c}\text { standardized } \\
\text { coefficients }\end{array}$} & T & Sig. \\
\cline { 1 - 5 } & $\mathrm{B}$ & Std.Error & beta & & \\
\hline (Constant) & -.298 & .368 & &.-810 & .419 \\
\hline BI & .520 & .063 & .466 & 8257 & .000 \\
\hline religiosity & .273 & .087 & .165 & 3144 & .002 \\
\hline KR & .252 & .052 & .272 & 4,820 & .000 \\
\hline
\end{tabular}

a. Dependent variables: KM

Source: SPSS output 